Conference Paper

\title{
Trenggalek Community Empowerement Model Base on Local Food Innovation
}

\author{
Didiek Tranggono ${ }^{1}$, Andre Yusuf Trisna*2, Praja Firdaus Nuryananda ${ }^{3}$ \\ ${ }^{1}$ Communication Studies, Faculty of Social and Political Science, Universitas Pembangunan Nasional \\ "Veteran" Jawa Timur, Indonesia \\ ${ }^{2}$ Food Technology, Faculty of Engineering, Universitas Pembangunan Nasional “Veteran” Jawa Timur, \\ Indonesia \\ 3International Relations, Faculty of Social and Political Science, Universitas Pembangunan Nasional \\ "Veteran" Jawa Timur, Indonesia
}

*Corresponding author:

E-mail:

andreyusuf.tp@upnjatim.ac.id

\begin{abstract}
Trenggalek is a regency that has abundant natural resources. Located in East Java, Trenggalek has agricultural, plantation, and fishery products. Unfortunately, some of its villages are categorized as underdeveloped villages (Desa Tertinggal). Tegaren village was once a village with IDT (Inpres Desa Tertinggal) status, which then often received assistance from the government. Whereas Winong village, a neighbor of Tegaren village, is also included in a developing village. Tasikmadu village, especially Watulimo Subdistrict, coastal area, is categorized as a developed village, but there are still many poor people. The research that we have done is the development of the ABCD (Asset-Based Community Development) model by Christopher Dureau which focuses on asset utilization. To determine the development of the ABCD method, this study used a mixed approach (mix method) with interview instruments, observation, and questionnaire distribution. This research will focus on developing and empowering communities in underdeveloped villages of Trenggalek Regency by focusing on local food innovation. The conclusion from this paper includes some reflections on the extent to which the concept of local food innovations. First must be there must be support from the government through both sustainable agriculture programs and food processing innovation. Second, to improve community capacity through systemic and controllable empowerment program. In the last, empowerment base on local food can help the capacity of the community to increase economic effect more widespread and sustainable change.
\end{abstract}

Keywords: Empowerment, Trenggalek, capacity building, food innovation, agriculture

\section{Introduction}

According to BPS data (2019), the number of poor people in March 2019 was 25.14 million people or $9.41 \%$ of the total population of Indonesia. It is consist of $6.69 \%$ in cities and $13.10 \%$ in villages. In March 2019, on average, poor households in Indonesia had 4.68 household members. Thus, the average poverty line per poor household is IDR 1,990,170, - / poor household / month. Community empowerment is one of the solutions to poverty alleviation. However, the facts on the ground show that these efforts encountered many obstacles. Efforts made are not friendly to elements of community locality, and do not pay attention to the role of the community as the subject of development so that the percentage of success is very small (Najih et al., 2006).

Trenggalek Regency has a very diverse topography, from the coast to mountainous areas. According to BPS (2018), the potential of Trenggalek Regency is quite diverse, including, Agriculture

\section{How to cite:}

Tranggono, D., Trisna, A. Y., \& Nuryananda, P. F. (2021). Trenggalek community empowerement model base on local food innovation. $5^{\text {th }}$ International Seminar of Research Month 2020. NST Proceedings. pages 206-209. doi: 10.11594/ nstp.2021.0931 
(rice, corn, beans, sugarcane) and farming (cloves, tobacco, durian, zalacca, mangosteen, coffee); tourism (Damas beach, Karanggongso beach, Pancer Cengkrong mangrove forest, Banyon hill, Gemblung mountain, Sepikul mountain peak, Lowo cave, Kedung Maron River); Food Processing (soy sauce, syrup, fish drying); Mining (ores, limestone, marble, manganese, diorite, and coal); and Trade and Services. However, the large potential that Trenggalek Regency has, several obstacles cause its people to still prosper. The villages in Trenggalek Regency are categorized as underdeveloped and developing. Winong Village is included in the Tugu sub-district. This village is underdeveloped and has an IDM score of 0.5457. Tegaren Village is still classified as a developing village with an IDM score of 0.618. Even though it has a developing status, it does not show any significant development in its nature from the local community. Apart from the potential of agriculture, Tegaren Village also has economic potential in the form of a tourist attraction

Based on that statement, a response emerged from the researcher to take a deeper look at the empowerment of village communities to create and develop local potential-based home industry businesses. Therefore, the main focus of this research is a community empowerment model and local potential-based innovation development in the Disadvantaged Village area of Trenggalek Regency. In this research, a model of community empowerment and development based on local potential in underdeveloped areas of Trenggalek Regency will be developed which will combine elements of strategic planning from the government with participatory planning to identify local problems and potentials.

\section{Material and Methods}

The combination approach used in this study is quantitative and qualitative approaches (Creswell, 2007). There are 4 (four) main stages in this research, namely: (1) the preliminary stage (exploration study) through literature studies and field studies to find out the conditions and problems faced by local potential-based communities (Reiter, 2017); (2) the formulation stage of the empowerment and development model; (3) the implementation stage of the empowerment and development model to test the effectiveness of the model; (4) The implementation, evaluation, refinement, and validation phase of the model as well as the dissemination of the model so that it can be used as a blueprint for community empowerment models based on local potential, especially in rural areas, both in villages in East Java and in other villages in Indonesia.

\section{Results and Discussion}

Tasikmadu Village, Watulimo District, Trenggalek Regency is a village located on the south coast of Trenggalek Regency. Tasikmadu Village has the potential for extraordinary natural wealth. This village has two beaches, namely Karanggongso beach and Prigi beach which have the potential to be developed into a minapolitan area based on both capture fisheries and aquaculture. In Watulimo District, in 2017 the production of marine capture fisheries reached 18,240.93 tonnes, while the perinana production of pond cultivation was 238.67 tonnes (BPS, 2018). These two beaches have the potential to be developed into modern tourist destinations but prioritize natural conservation values or commonly known as ecotourism (DeLind \& Bingen, 2005).

Winong Village is included in the Tugu sub-district. This village is underdeveloped and has an IDM score of 0.5457. In contrast to Tasimadu Village, Winong Village has a topography that is dominated by lowlands with Mediterranean soil types (BPS, 2018). The majority of the two residents have their livelihoods as farmers. According to the Dinas Perhutbun Kab. Trenggalek (2010), stated that rice, maize, cassava, and sweet potato are the leading agricultural commodities. In the rainy season, farmers in Winong Village cultivate rice crops, and in the dry season, they replace it with corn, cassava and tobacco. Apart from being farmers, some residents also raise chickens and goats for livestock.

Tegaren Village has an area of 522.76 hectares. The village, which is included in the Tugu subdistrict, has a State Forest area of around 120 hectares. In general, the geographical and social 
conditions of Tegaren Village are similar to those of Winong Village. The majority of the livelihoods of the villagers are farming. Rice, maize, and cassava are the main commodities of Tegaren village. Apart from the agricultural sector, Tegaren Village is also known as a producer of bamboo matting. Until now, Tegaren Village is still classified as a developing village with an IDM score of 0.618. Even though it has a developing status, it does not show any significant development that is from the local community.

Seeing the natural resource potential of Winong and Tegaren Villages, many opportunities can be done to improve the status of the village to become a developed village. However, from observations in the field there were several obstacles / problems faced by the two villages. Winong and Tegaren villagers have, on average, a low level of education. The majority of parents $>40$ years old have primary and secondary school education, while the adult group, aged 20-40 years, is dominated by senior high school graduates. The people of Winong and Tegaren villages, which are classified as lowland and mountainous areas, are still hampered by the culture / habits of the people who tend to be quiet and less enthusiastic about innovating. This causes the need for knowledge transfer from outside parties to increase community capacity. At the village government level, the allocations for ADD and DD are still prioritized for physical development. There has not been any scale effort by the village government to build assets that can be used for community income sources.

According to field observations, innovation did not move at all because in the three villages there were no local champions who were allowed to develop their villages. The village leader, namely the Village Head, as the spearhead of village development, should be able to produce and have a new local champion and then jointly develop, form collective action of all residents through the hamlet head. Consciously, this process must be carried out in a bottom-up manner as suggested by Houghton (2015), but in implementation in the field, it is very difficult to implement. Therefore, in the process of empowering and developing the villages of Tasikmadu, Winong, and Tegaren, it must still be done in a top-down manner through the respective village and hamlet heads.

This research produces several indicators that are needed for an underdeveloped village to innovate and advance. These indicators include the strong and innovative leadership of the regional head, an open and entrepreneurial culture of the local community, and ownership of assets by underdeveloped villages. These three indicators will be further developed in the second year so that the empowerment of communities in disadvantaged villages will be based on three major aspects, namely 1) leadership, 2) culture, and 3) entrepreneurship.

Only Tasikmadu Village with this new village head can be present as a strong and promising institution full of innovation. Tasikmadu Village does have a different character from Winong and Tegaren. Tasikmadu, which is located in a coastal area, is helped by the culture of coastal people who are hardworking and never give up. This is in line with Manumono (2008), which states that coastal communities tend to be violent and aggressive. This turned out to be influenced by the condition of the coastal environment which is hot and open, which makes fishing families easy to be provoked.

In contrast to Tasikmadu village, until now the development and empowerment in Tegaren and Winong Villages have not been able to have a significant impact either on the growth of innovation or the sustainability of these innovations. The culture of rural people who are simple, accept what they are, uphold "upload-upload", harmonious relationship, but have a closed feeling in terms of criticism, it is suspected that the development of the village cannot be carried out. Tegaren and Winong villagers tend to accept current conditions and tend to find it difficult to carry out activities that are new and foreign. 


\section{Conclusion}

1. Villages in Trenggalek Regency are underdeveloped and developing. Winong Village has an IDM score of 0.5457 , Tegaren Village is classified as a developing village with an IDM score of 0.618 .

2. The villages in Trenggalek Regency have natural potential and abundant agricultural products such as rice, cassava, maize, and plantations such as cloves, and fisheries such as marine and inland water products.

3. The empowerment model based on innovation development by increasing the role of local champions is one of the solutions that can be implemented in Trenggalek Regency.

\section{References}

Badan Pusat Statistik. (2018). Kabupaten Trenggalek dalam angka 2018.https://trenggalekkab.bps.go.id/publication/2018/08/16/95a93f521b7a35d1e6d7187f/kabupaten-trenggalek-dalam-angka-2018.html

Badan Pusat Statistik. (2019). Presentase penduduk miskin di Indonesia. https://www.bps.go.id/pressrelease/2019/07/15/1629/persentase-penduduk-miskin-maret-2019-sebesar-9-41-persen.html..

Creswell, J. W. (2007). Qualitative inquiry and research design: Choosing among five approaches. Thousand Oaks, CA: Sage.

DeLind, L., Bingen, J., (2008). Place and civic culture: Re-thinking the context for local agriculture. Journal of Agricultural and Environmental Ethics, 21, 127-151.

Houghton, J. (2015). (Regional and) local economic development themes in contemporary South African Cities. Local Economy, 31(12), 42-56. doi:10.1177/0269094215621733

Manumono, D. (2007). Dampak abrasi dan ROB terhadap perilaku masyarakat kawasan pesisir di Kabupaten Demak. Yogyakarta: Instiper.

Najih, M., Watch, M.C., Indonesia, Y.P.P.I., \& K.M. (2006). Hak rakyat mengontrol negara: membangun model partisipasi masyarakat dalam penyelenggaraan otonomi daerah. Diterbitkan atas kerjasama Malang Corruption Watch (MWC) [dengan] Yappika

Reiter, B. (2017). Theory and methodology of exploratory social science research, in Government and International Affairs Faculty Publications, 132. 